U.S. DEPARTMENT OF THE INTERIOR

U.S. GEOLOGICAL SURVEY

\title{
MAP SHOWING SAND AND GRAVEL DEPOSITS IN THE \\ BIGFORK-AVON AREA, FLATHEAD, LAKE, LEWIS AND CLARK, MISSOULA, AND POWELL COUNTIES, MONTANA
}

By Irving J. Witkind 